\title{
Nutritional and Temporal Effects on Hypopharyngeal Glands of Africanized Honeybees (Hymenoptera - Apidae)
}

by

Fábio de Assis Pinto ${ }^{1}$, Renata Oliveira de Fernades ${ }^{2}$, Júlio César Melo Poderoso르, Weyder Cristiano Santana ${ }^{2 *}, \&$ Dejair Message ${ }^{3}$

\section{ABSTRACT}

The hypopharyngeal gland ( $\mathrm{HG}$ ), along with the mandibular gland from Apis mellifera workers plays a fundamental role on the development of the hive. The protein based substances produced by the hypopharyngeal and mandibular glands are two important component of the royal jelly, which is responsible for caste differentiation and used to feed larvae, drones and the queen. Several factors may alter the physiology of glandular structures in honeybees and consequently their role within the beehive, and one of the most important factors is their nutritional status. However, few studies have evaluated the development of HG against different diets on Africanized honeybees. Our experiment was composed of four diets (treatments) offered to different groups of workers: (T1) honey, (T2) honey + soybean extract, (T3) honey + pollen and (T4) sucrose solution. The development of the glands was evaluated in two periods: 7 and 10 days of exposure to the diet types. According to the results, an interference of the diet on the acini area of the HG was observed. Bees that were fed with the sucrose solution or soybean extract presented the smallest acini areas as compared to the other treatments. The time of exposure to the different types of diets also had an effect on acini areas. Worker bees fed with honey and soybean extract for 10 days presented smaller acini areas when compared to bees dissected at the $7^{\text {th }}$ day of exposure to those same diet types. Nevertheless, we also observed that factors other than just nutrition are important to the full development of the HG, such as the stimulus promoted by the young breeds.

\footnotetext{
${ }^{1}$ Postgraduate Programme in Entomology, Entomology Department, Federal University of Viçosa, Brazil.

${ }^{2}$ Entomology Department, Federal University of Viçosa, Brazil.

${ }^{3}$ Agency for Agrobusiness Technology in the State of São Paulo, Brazil.

${ }^{*}$ Correspondence author: Weyder Cristiano Santana, Entomology Department, Federal University of Viçosa, PH Rolfs Avenue, s/n, Zip Code: 36571-000, Viçosa, Minas Gerais, Brazil.

e-mail:weyder.santana@ufv.br
} 
Key words: nutrition, hypopharyngeal glands, pollen, Apis mellifera, royal jelly

\section{INTRODUCTION}

The quality of food collected by honeybees has an important relationship to the overall hive development, and special attention must be given to the role that food plays on the development of the hypopharyngeal glands (HG) (Wcislo and Cane 1996). HG of workers of Apis mellifera L. (Hymenoptera: Apidae) have been morphologically and physiologically studied due to their importance on the production of royal jelly (Cruz-Landim 2009; Seehuus et al. 2007; Gatehouse et al. 2004). However, few studies have evaluated the development of glands in Africanized honeybees as a function of the diet offered to them. The HG, located inside the worker's head, produces a protein-based substance that is responsible for the differentiation among castes and also used to feed young larvae, drones and the queen (Feng et al. 2009; Kamakura 2011).The structure of this gland varies according to the age and function of workers within the hive. Young honeybees that function as nurses have active $\mathrm{HG}$ with large acini, while in older honeybees that present foraging activity, the gland will tend to be atrophied (Sasagawa et al.1989).

Several factors may affect the physiology of glands and consequently the honeybee's role, impacting hive internal condition or organization (Huang \& Ottis 1989). One important factor is the nutritional state of the honeybees. Protein sources are extremely important to physiological development, especially to the young workers, as pollen is the main source of protein to their development (Zahra \& Talal 2008). The activity period of the HG and the time that honeybees spend as nurses may vary according to the number of larvae in the hive. Apparently, the activation of the HG will occur with the presence of a protein based food, and the maintenance of the active glands will depend on the existence of larvae in the hive (Huang \& Ottis 1989; AlGhamdi et al. 2011).

During periods of the year characterized by pollen scarcity, other food sources rich in protein such as soybean extract and milk powder might be used to feed the hives (Zahra and Talal 2008; DeGrandi-Hoffman et al. 2010; Al-Ghamdi et al. 2011). However, despite those diets' high protein contents, their protein types may not be digested or absorbed by the bees, 
resulting in a negative impact on the overall development of the hive (Pernal \& Currie 2000). Several factors should be considered regarding the types of food offered to the honeybees, being that food organoleptic characteristics are fundamental to acceptance and ingestion of the diet, while food nutrient composition is important to its digestion and assimilation.

The role of the HG on the production of royal jelly provides motivation for improving the current knowledge on the development of adequate diets that stimulate the development of the glands with the aim of empowering the production of this apicultural product of great nutritional properties. In this context, the aim of this study was to evaluate the effect of different diets on the development of HG of Africanized honeybees.

\section{MATERIAL AND METHODS}

The study was conducted at the Central Apiary of the Federal University of Viçosa (UFV), where young workers of Africanized Apis mellifera were collected directly from the combs. The workers were confined inside wood boxes $(09 \times 09 \times 03 \mathrm{~cm})$, covered with nylon screens, and fed with the diets and wter ad libitum. The experiment consisted of four treatments (diets): honey only (T1), a mixture of soybean extract and honey (4:1) (T2), a mixture of pollen and honey (4:1) (T3), and a 50\% p/v solution of sucrose only(T4). Twelve wood boxes, each containing 10 young workers were mounted; each treatment had three replicates. The boxes were kept inside environmentally controlled chambers at $34 \pm 2{ }^{\circ} \mathrm{C}$ and $70 \pm 10 \%$ RU.

The honeybees from each treatment were dissected after two different periods: at the $7^{\text {th }}$ and $10^{\text {th }}$ day of exposure to the diets. Prior to being dissected, five honeybees were taken from each box and kept in a fixing solution of Dietrich (30 $\mathrm{ml}$ of ethanol, $10 \mathrm{ml}$ of formaldehyde $40 \%, 2 \mathrm{ml}$ of acetic acid and $58 \mathrm{ml}$ of distilled water) for a two day period, and then they were transferred to an $80 \%$ ethanol solution. After the fixing period, the honeybees were dissected, and their HGs were extracted for subsequent measurement of an area of 20 acini per honeybee. Photographic images were taken and recorded with an optical microscope (100X magnification). The acini areas were determined with the software Image Pro Plus. The obtained data of acini areas from $\mathrm{HG}$ of honeybees fed with different types of diets after two different periods of exposure ( 7 and 10 days) were submitted to ANOVA and the Tukey Test $(\mathrm{p}<0.05)$. 


\section{RESULTS}

The type of diet offered to the honeybees did affect mean acini area values $(\mathrm{F}=17.78 ; \mathrm{p}<0.05)$. Smaller acini areas were observed for honeybees fed with sucrose solution (T4) $\left(2.5 \mu \mathrm{m}^{2}\right)$, followed by honeybees fed with honey + soybean extract $(\mathrm{T} 2)\left(4.0 \mu \mathrm{m}^{2}\right)$. The time factor also had a significant effect on acini areas $(\mathrm{F}=11.00 ; \mathrm{p}<0.05)$, with negative correlation (Table 1$)$.

Honeybees that were fed with honey + soybean extract (T2) for 10 days presented smaller acini areas as compared to honeybees fed with the same feed for a 7 days period. Acini areas of honeybees fed with pollen (T3) after 7 or 10 days of exposure were not statistically different. However, it was observed that the general morphology of the acini for the four treatments presented a poor development when compared to acini extracted from HG of nursing bees aging from 7 to 10 days, taken from hives with young larvae and queen (Fig. 1).

Table 1 - Acini area in HG in workers of Africanized honeybees $\left(\mu \mathrm{m}^{2}\right)$

\begin{tabular}{lcc}
\hline \hline Feed & \multicolumn{2}{c}{ Time (days) } \\
& 7 & 10 \\
\hline Honey & $5.6 \pm 0.95 \mathrm{aA}$ & $3.2 \pm 0.50 \mathrm{bB}$ \\
Honey + Soybean extract & $5.2 \pm 0.75 \mathrm{aA}$ & $2.8 \pm 0.40 \mathrm{bB}$ \\
Honey + Pollen & $5.7 \pm 0.90 \mathrm{aA}$ & $5.5 \pm 0.90 \mathrm{aA}$ \\
Sucrose & $2.0 \pm 0.55 \mathrm{bA}$ & $3.1 \pm 0.55 \mathrm{bA}$ \\
\hline
\end{tabular}

Means followed by the same letters (capital letters for rows and small letters for columns) do not statistically differ among one another using the Tukey Test at $5 \%$ probability. Mean \pm standard error.

\section{DISCUSSION}

The secretion produced by the HG is the main constituent of the royal jelly, a substance rich in protein and other nutrients that feeds young larvae, helps in caste differentiation due to its morphogenetic properties and is also the exclusive nutrient source for the queen (Michener 2007; Kamakura 2011). However, the development or activation of this structure is linked to some factors such as protein availability and quantitative or qualitative variations of this resource (Al-Ghamdi et al. 2011). The results obtained from this study demonstrated that the type of diet does affect the development of the workers' 


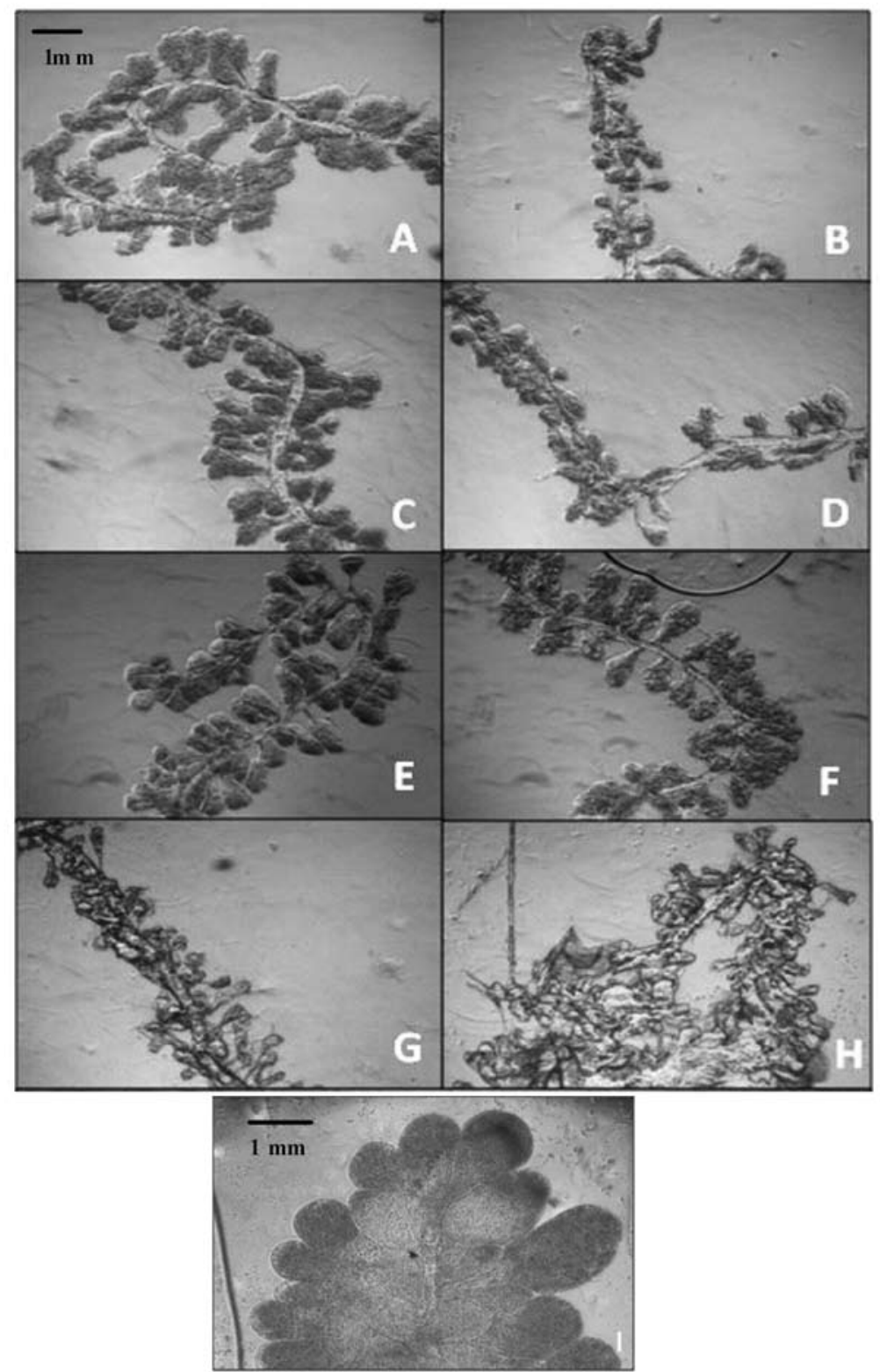

Fig. 1. Acini extracted from Apis mellifera fed with different diets, without the stimulating presence of young larvae. A) T1 - Honey, 7 days; B) T1 - Honey, 10 days; C) T2 - Honey + soybean extract, 7 days; D) T2 - Honey + soybean extract, 10 days; E) T3 - Honey + pollen, 7 days; F) T3 - Honey + pollen, 10 days; G) T4 -50\%sucrose solution, 7 days; H) T4 -50\%sucrose solution, 10 days. I) Hypopharyngeal gland of a nursing bee kept inside the beehive containing larvae and queen. 
glands, as the best results were observed for the group fed on treatment T3 (honey + pollen). Protein availability affected the size of acini, as groups of honeybees fed with protein supplements presented acini with greater areas as compared to groups that were fed exclusively with pollen and/or honey (DeGrandi-Hoffman et al. 2010).

Food palatability and absorption are factors that should be taken into account when providing honeybees with supplemental diets. Supplements with greater protein content may not always be the most efficient (Al-Ghamdi et al. 2011; DeGrandi-Hoffman et al. 2010). In other words, because they are not naturally part of a honeybee diet, foods based on soybean extract might be rejected or only consumed in small amounts for not presenting attractive organoleptic characteristics.

When evaluating food protein concentration and the development of the HG in Carniolan bees, Al-Ghamdi et al. (2011) verified a better development of the structure in those that were fed with apicultural pollen, even though other groups of the same type of bees were fed up on rations with higher protein contents and presented underdeveloped glands. Al-Ghamdi et al. (2011) also observed that the consumption of diets based on soybean extract, milk powder and brewer's yeast was $56.63 \%$ smaller than the consumption of diets based on apicultural pollen. Hence, the development of diets containing fractions of apicultural pollen in their composition might be a good solution to reduce aversion to diets and increase the nutrient absorption by the honeybees, resulting in better overall development of the hive and improved production of royal jelly.

Even though the results obtained from this study show significant differences among treatments, for all cases the HG presented as poorly developed, with small and apparently atrophied acini as compared to those belonging to the nursing bees. One factor that might explain this difference in development was the absence of young brood, which might act as a stimulus to the development and activation of the HG, as observed in natural conditions (Huang \& Ottis 1989). These glands are significantly bigger in the presence of young brood and will tend to reduce in size a few days of their absence inside the hives. Thus, even with adequate protein sources, the full development and maintenance of this structure will only occur under the presence of young brood (Huang \& Ottis 1989; Mohammedi et al. 1996). 
Along with the presence of pupae and good sources of protein, nutritional supplementation may also affect the development of the HG. Zahra and Talal (2008) observed that the effect of supplemental feeding in hives of $A$. mellifera promoted an increase in mean acinus size and HG ducts length, being that highervalues were obtained in hives supplemented with vitamin C, overcoming supplements based on soybean extracts. Factors such as parasitism may also have a negative impact on glands development. Pinto et al. (2011) observed a cell area decrease of $11 \%$ for HGs in Africanized honeybees parasitized by the mite Varroa destructor, as compared to healthy honeybees.

Role assignment within hives with $A$. mellifera is directly related to the age of the workers, and this fact is due to physiological changes triggered by hormones mediated by biogenic amines as the honeybees get older (Otto 1955; Huang \& Otis 1989).These physiological changes cause the young workers of $A$. mellifera not to present active or developed HG right after the bee's emergence, so that they will perform tasks as cleaning the hive; afterwards, when they reach 6 to 12 days of age, the glands reach their full development, and the bees will then act as nurses (Otto 1955; Huang \& Otis 1989). Thus, along with the availability of the necessary nutrients to the development and activation of the glands in workers, the nursing behavior due to the presence of the brood is an important factor for the maintenance of the HG activity (Huang \& Ottis 1989).

Significant decrease in acini areas was observed in honeybee groups fed with soybean extract and honey, while groups of bees from the same study that were fed either with pollen, honey or sucrose presented mean acini areas statistically of the same size. The decrease in acini areas observed in workers fed only with honey is due to the lack of enough protein resources for the maintenance of the gland activity associated with the lack of stimulus from the brood; for honeybees fed with soybean extract and honey, the results can be explained by the aversive behavior to the non-natural protein source combined with the lack of stimulus due to the absence of brood. Pernal and Currie (2000), when analyzing the effect of the quality of several types of pollen on the protein secretion of the HG of workers, observed a significant decrease in secretion amount between 7 and 10 days according to the nutritional quality and acceptance of the pollen product offered to the workers. 
The group that was fed solely with a sucrose solution presented the smallest acini area values, as there were no significant difference for workers after either 7 or 10 days. This outcome is in agreement to what was presented by Pernal and Currie (2000), who did not observe differences, for the same age periods, in the amount of protein secretion from glands of honeybees fed on sources of inferior nutritional values. In contrast, the group in this study that was fed with a diet containing pollen and honey, which presented acini areas significantly bigger than those obtained from the other dietetic treatments, did not differ between the ages of 7 and 10 days.

The best results for acini area was obtained from the honeybee group fed with their natural protein source (pollen), even though the bees in this treatment did not have their HG fully developed. This outcome may be valuable in the development of supplemental diets for hives during periods of natural food scarcity. In order to reduce the costs, diets that combine pollen with other protein sources should be tested in future studies to evaluate the development of the HG and other structures such as the mandibular glands. Providing the hives with an adequate diet might also act as a means to prevent the occurrence of pathogens and epizootics such as CCD, which has been the cause of millions in losses to the apicultural business worldwide (Brodschneider \& Crailsheim 2010).

\section{CONCLUSION}

The results obtained from the study described in this document reinforce the hypothesis that feeding plays an important role on the initial development of $\mathrm{HG}$, and that different diets will affect gland development to different degrees, according to diet nutritional values. However, regardless of the type of food, the glands of the honeybees used in this study presented themselves to be less active and tended to present smaller sizes during the entire experimental period due to the absence of brood, which are necessary and act as a stimulus towards full gland development and maintenance.

\section{ACKNOWLEDGEMENTS}

The authors would like to thank Gecelmino Correia for helping with the colony management. We also thank FAPEMIG, CNPq and CAPES for supporting this work. 


\section{REFERENCES}

Al-Ghamdi, A.A., A.M. Al-Khaibari \& M.O. Omar. 2011. Consumption rate of some proteinic diets affecting hypopharyngeal glands development in honeybee workers. Saudi Journal of Biological Sciences 18:73-77.

Brodschneider, R. \& K. Crailsheim. 2010. Nutrition and health in honey bees. Apidologie 41: 278-294.

Cruz-Landim, C. 2009. Abelhas: morfologia e função de sistemas. São Paulo: Ed UNESP, 416p.

Gatehouse, H.S., L.N. Gatehouse, L.A. Malone, S. Hodges, E. Tregidga \& J. Todd. 2004. Amylase activity in honey bee hypopharyngeal glands reduced by RNA interference. Journal of Apicultural Research 43:9-13.

DeGrandi-Hoffman, G., Y. Chen, E. Huang \& M.H. Huang. 2010. The effect of diet on protein concentration, hypopharyngeal gland development and virus load in worker honey bees (Apis mellifera L.). Journal of Insect Physiology 56:1184-1191.

Feng, M., Y. Fang \& J. Li. 2009. Proteomic analysis of honeybee worker (Apis mellifera) hypopharyngeal gland development. BMC Genomics 10:645-657.

Kamakura, M. 2011. Royalactin induces queen differentiation in honeybees. Nature 473:478-483.

Huang,Z.Y.\&Z.W. Otis. 1989. Factors determining hypopharingeal gland activity of worker honey bees (Apis mellifera L.). Insectes Sociaux 36:264-276.

Michener, C.D. 2007. The bees of the world. Baltimore: The Johns Hopkins University Press. 953 p.

Mohammedi A., D. Crauser, A. Paris \& Y. Le Conte. 1996. Effect of a brood pheromone on honeybee hypopharyngeal glands. ComptesRendus de l'Académie des Sciences - Series III 319:769-772.

Otto, V.D. 1955. Die Pharynxdriise der Honigbiene (Apis rnellifera L.) bei Prowona $=$ Hele $=$ Nahrung als Pollennersatz. Archiv fur Geffiigelrucht und Kleintievkunde 4:209-240.

Pernal, S. F. \& R.W. Currie 2000. Pollen quality in fresh and 1-year-old single pollen diets for worker honey bees (Apis mellifera L.). Apidologie 31:387-409.

Pinto, F.A, G.K. Souza, M.A. Sanches \& J.E. Serrão 2011. Parasitic Effects of Varroa destructor (Acari: Varroidae) on Hypopharyngeal Glands of Africanized Apis mellifera (Hymenoptera: Apidae). Sociobiology 58 (3): 769-778.

Sasagawa, H., M. Sasaki \& I. Okada 1989. Hormonal control of the division of labor in adult honeybees (Apis mellifera L.). I. Effect of methoprene on corpora allata and hypopharyngeal gland, and its $\alpha$-glucosidase activity. Applied Entomologyand Zoology24:66-77.

Seehuus, S., K. Norberg, T. Krekling, K. Fondrk \& G.V. Amdam 2007. Immunogold localization of vitellogenin in the ovaries, hypopharyngeal glands and head fat bodies of honeybee workers, Apis mellifera. Journal of Insect Science 7:52-60.

Wcislo, W.T., \& J.H. Cane 1996. Floral resource utilization by solitary bees (Hymenoptera: 
Apoidea) and exploitation of their stored foods by natural enemies. Annual Review of Entomology 41: 257-286.

Zahra A. \& M. Talal 2008. Impact of pollen supplements and vitamins on the development of hypopharyngeal glands and brood area in honey bees. Journal of Apicultural Science 52:5-12.

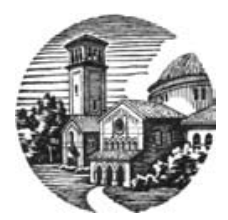

